Subscriber access provided by SCD Université de Rennes1 | SCD de l'Université de Rennes 1

Environmental Modeling

\title{
Kinetic study on clogging of a geothermal pumping well triggered by mixing-induced biogeochemical reactions
}

Luc Burte, Charles Cravotta, Lorine Bethencourt, Julien Farasin, Mathieu Pédrot, Alexis

Dufresne, Marie-Françoise Gerard, Catherine Baranger, Tanguy Le Borgne, and Luc Aquilina

Environ. Sci. Technol., Just Accepted Manuscript • DOI: 10.1021/acs.est.9b00453 • Publication Date (Web): 30 Apr 2019

Downloaded from http://pubs.acs.org on May 9, 2019

\section{Just Accepted}

"Just Accepted" manuscripts have been peer-reviewed and accepted for publication. They are posted online prior to technical editing, formatting for publication and author proofing. The American Chemical Society provides "Just Accepted" as a service to the research community to expedite the dissemination of scientific material as soon as possible after acceptance. "Just Accepted" manuscripts appear in full in PDF format accompanied by an HTML abstract. "Just Accepted" manuscripts have been fully peer reviewed, but should not be considered the official version of record. They are citable by the Digital Object Identifier (DOI®). "Just Accepted" is an optional service offered to authors. Therefore, the "Just Accepted" Web site may not include all articles that will be published in the journal. After a manuscript is technically edited and formatted, it will be removed from the "Just Accepted" Web site and published as an ASAP article. Note that technical editing may introduce minor changes to the manuscript text and/or graphics which could affect content, and all legal disclaimers and ethical guidelines that apply to the journal pertain. ACS cannot be held responsible for errors or consequences arising from the use of information contained in these "Just Accepted" manuscripts. 
1 Kinetic study on clogging of a geothermal pumping $2 \quad$ well triggered by mixing-induced biogeochemical reactions

4 Luc Burté †t* $^{*}$, Charles A. Cravotta III ${ }^{\S}$, Lorine Bethencourt ${ }^{\dagger / l}$, Julien Farasin ${ }^{\dagger}$, Mathieu Pédrot ${ }^{\dagger}$, 5 Alexis Dufresne"l, Marie-Françoise Gérard ${ }^{\dagger}$, Catherine Baranger ${ }^{*}$, Tanguy Le Borgne ${ }^{\dagger}$, Luc Aquilina ${ }^{\dagger}$

†Univ Rennes, CNRS, Géosciences Rennes - UMR 6118 - Av. Général Leclerc - F-35042 Rennes Cedex, France

11 ॥Univ Rennes, CNRS, Écobio - UMR 6553 - Av. Général Leclerc - F-35042 Rennes Cedex,

$14 *$ Corresponding author: burte.luc@gmail.com 


\section{ABSTRACT}

16 The sustainability of ground-source geothermal systems can be severely impacted by

17 microbially mediated clogging processes. Biofouling of water wells by hydrous ferric oxide is a

18 widespread problem. Although the mechanisms and critical environmental factors associated with

19 clogging development are widely recognized, effects of mixing processes within the wells and

20 time scales for clogging processes are not well characterized. Here we report insights from a joint

21 hydrological, geochemical and metagenomics characterization of a geothermal doublet in which

22 hydrous ferric oxide and hydrous manganese oxide deposits had formed as a consequence of

23 mixing shallow groundwater containing dissolved oxygen and nitrate with deeper, anoxic

24 groundwater containing dissolved iron $\left(\mathrm{Fe}^{\mathrm{II}}\right)$ and manganese $\left(\mathrm{Mn}^{\mathrm{II}}\right)$. Metagenomics identify

25 distinct bacteria consortia in the pumping well oxic and anoxic zones, including autotrophic iron-

26 oxidizing bacteria. Batch mixing experiments and geochemical kinetics modeling of the associated

27 reactions indicate that $\mathrm{Fe}^{\mathrm{II}}$ and $\mathrm{Mn}^{\mathrm{II}}$ oxidation are slow compared the residence time of water in

28 the pumping well; however, adsorption of $\mathrm{Fe}^{\mathrm{II}}$ and $\mathrm{Mn}^{\mathrm{II}}$ by accumulated hydrous ferric oxide and

29 hydrous manganese oxide in the well bore and pump riser provides "infinite" time for surface-

30 catalyzed oxidation and a convenient source of energy for iron-oxidizing bacteria, which colonize

31 the surfaces and also catalyze oxidation. Thus, rapid clogging is caused by mixing-induced redox

32 reactions and is exacerbated by microbial activity on accumulated hydrous oxide surfaces.

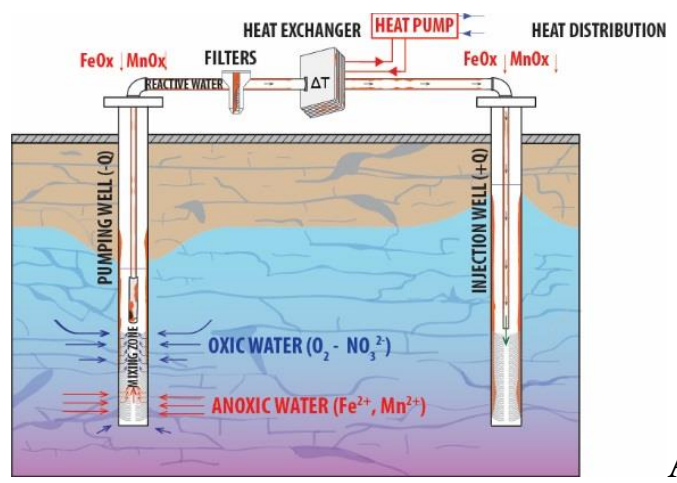

Abstract art $(4.76 \times 8.47 \mathrm{~cm})$ 


\section{INTRODUCTION}

35 Ground-source geothermal heating and cooling technologies can alleviate the use of fossil

36 carbon energy and reduce greenhouse gas emissions to the atmosphere ${ }^{1}$. The technology of open-

37 loop systems with direct transfer of energy from groundwater through a heat exchanger between

38 pumping and injection wells (doublets) can be particularly cost-effective for heating and cooling

39 buildings. Yet, the major issue associated with shallow geothermal doublets is the clogging of

40 wells, exchangers, filters and other surface equipment by "biofouling" deposits that consist of

41 mineral ${ }^{2-5}$ and microbial ${ }^{6-9}$ encrustations. Guaranteeing the sustainability of a groundwater heat

42 pump system is challenging because of the rapidity at which such biofouling may appear, during

43 the first year of exploitation in some cases observed by the authors. Clogging issues are also

44 common in other groundwater sectors such as drinking water production ${ }^{10-12}$, managed aquifer

45 storage and recovery ${ }^{13,14}$, and dewatering systems ${ }^{15,16}$. Although the processes at the origin of

46 biogeochemical clogging have been described ${ }^{17-19}$, the critical variables affecting hydrogeological

47 and biogeochemical processes driving well biofouling are poorly characterized ${ }^{20}$. This is

48 particularly true for unstable field parameters that can vary spatially and temporally with

49 consequent effects on reaction development and rates, especially in the context of geothermal

50 systems where neighboring geothermal doublets may exhibit different sensitivities to clogging, as

51 illustrated in the present study.

52 Physical, chemical and microbiological processes contribute to clogging. Iron and manganese

53 oxide (bio)mineralization is the most common cause of clogging encountered in water systems

54 supplied by groundwater ${ }^{21-23}$. These clogging deposits form when anoxic groundwater containing

55 dissolved iron $\left(\mathrm{Fe}^{\mathrm{II}}\right)$ and manganese $\left(\mathrm{Mn}^{\mathrm{II}}\right)$ mixes with water containing oxygen ${ }^{2}$ or, possibly,

56 nitrate $^{24}$ (Equations 1-7). 


$$
\begin{aligned}
& \text { Fe } e^{I I} \text { Oxidation by Oxygen : } \mathrm{Fe}^{2+}+\frac{1}{4} \mathrm{O}_{2}+\mathrm{H}^{+} \rightarrow \mathrm{Fe}^{3+}+\frac{1}{2} \mathrm{H}_{2} \mathrm{O} \\
& \text { Fe } e^{I I} \text { Oxidation by Nitrate : } \mathrm{Fe}^{2+}+\frac{1}{5} \mathrm{NO}_{3}{ }^{-}+\frac{6}{5} \mathrm{H}^{+} \rightarrow \mathrm{Fe}^{3+}+\frac{1}{10} \mathrm{~N}_{2}+\frac{3}{5} \mathrm{H}_{2} \mathrm{O} \\
& \mathrm{Fe}^{\mathrm{III}} \text { Hydrolysis : } \mathrm{Fe}^{3+}+3 \mathrm{H}_{2} \mathrm{O} \rightarrow \mathrm{Fe}(\mathrm{OH})_{3} \downarrow+3 \mathrm{H}^{+} \\
& \text {Mn } n^{I I} \text { Oxidation: } \mathrm{Mn}^{2+}+\frac{1}{4} \mathrm{O}_{2}+\mathrm{H}^{+} \rightarrow \mathrm{Mn}^{3+}+\frac{1}{2} \mathrm{H}_{2} \mathrm{O} \\
& \mathrm{Mn}^{I I I} \text { Hydrolysis : } \mathrm{Mn}^{3+}+2 \mathrm{H}_{2} \mathrm{O} \rightarrow \mathrm{MnOOH} \downarrow+3 \mathrm{H}^{+} \\
& \text {Disproportionation: } 2 \mathrm{MnOOH}+2 \mathrm{H}^{+} \rightarrow \mathrm{MnO}_{2}+\mathrm{Mn}^{2+}+2 \mathrm{H}_{2} \mathrm{O} \\
& \mathrm{Mn}^{I V} \text { reduction : } \mathrm{MnO}_{2}+2 \mathrm{Fe}^{2+}+4 \mathrm{H}_{2} \mathrm{O} \rightarrow 2 \mathrm{Fe}(\mathrm{OH})_{3}+\mathrm{Mn}^{2+}+2 \mathrm{H}^{+}
\end{aligned}
$$

57 Mixing of oxic and anoxic groundwater can occur through different pathways: (1) oxygen-rich

58 recharge water can infiltrate the aquifer due to pumping and mix with reduced groundwater near

59 the well bore ${ }^{12,25,26}$, (2) intermittent pumping can cause fluctuation of the water table and

60 oxygenation of anoxic groundwater by air entrapment ${ }^{27-31}$, (3) mixing of chemically

61 heterogeneous water bodies in aquifers characterized by localized oxidizing condition (i.e. rich in

$62 \mathrm{O}_{2}, \mathrm{NO}_{3}{ }^{-}$) and reducing condition (i.e. rich in $\mathrm{Fe}^{2+}, \mathrm{Mn}^{2+}$ ) at different depths or spatially ${ }^{2}$. Despite

63 the suspected role of mixing-induced biogeochemical reactions in clogging phenomena, field

64 evidence demonstrating the impact is sparse $\mathrm{e}^{32-34}$. Microbiological communities are known to be

65 involved in clogging; ${ }^{17-19,23,35}$ however, detailed information on where and when clogging can

66 occur and potential competition with chemical oxidation is lacking for field conditions ${ }^{36,37}$. In the

67 context of geothermal doublets, where fluid residence times in the geothermal loop are brief

68 (typically few minutes), the mechanisms leading to observed rapid clogging of the system have

69 not been quantified.

70 Field measurements, batch incubation experiments, and geochemical kinetics modeling were

71 conducted to provide a quantitative framework for the prediction of clogging of geothermal wells.

72 An interdisciplinary field campaign was conducted to characterize the key environmental variables 
73 involved in mixing induced reactions that cause well clogging, including flow distribution and

74 chemical heterogeneity within the well. A metagenomic study was carried out to investigate

75 microbiological diversity and the potential roles of identified taxa in the chemical reactions. Batch

76 incubation experiments, which included native microbes but excluded previously accumulated

77 sorbent or biofilms, were used to demonstrate rates of change in solution chemistry that result from

78 mixing of water from oxic and anoxic zones in the well. A geochemical kinetics model was then

79 developed to simulate the mixing of the oxic and anoxic waters and observed decreases in

80 dissolved iron and manganese concentrations in the simple batch system (homogeneous kinetics)

81 and in the pumping well system where accumulated precipitate acts as a sorbent (heterogeneous

82 kinetics) within the gravel pack, well bore, and pump. Field observations and modeling results that

83 consider variations in microbial catalysis of $\mathrm{Fe}^{\mathrm{II}}$ oxidation demonstrate how chemical

84 heterogeneity and biogeochemical reactions promoted by pumping-induced mixing of oxic and

85 anoxic waters can lead to rapid clogging of geothermal loops.

\section{MATERIALS AND METHODS}

89 Orléans (France) that began operation in October 2011, but eventually failed due to clogging.

90 Technical information on well construction is summarized in table SI.1 (supporting information).

91 Doublet DGSY extracts groundwater from the limestone aquifer "Calcaire de Pithivier," which

92 exhibits local karstification. The aquifer is unconfined and vulnerable to contamination as

93 indicated by locally elevated concentrations of volatile organic compounds (1,2-dichloroethene,

94 chloroform, trichloroethylene and methyl tertiary-butyl ether) and other unidentified organics that

95 were documented before clogging. Operators report that during the first heating season (winter

96 2011-2012), the heat exchanger was clogged by reddish-brown deposits. Operators tried to 
97 maintain the geothermal doublet, however, after multiple rehabilitation efforts, the well pump was

98 removed in May 2016. The pump and the riser pipe were coated by slimy reddish-brown

99 encrustations on the outer surface and underlying hard black deposits on the inner surface (Figure

100 SI.1 in supporting information). The deposits caused a reduction of $20-30 \%$ of the inner diameter

101 of the riser pipe. Such biofouling was also likely to have accumulated in the well bore and,

102 possibly, in the screen and gravel pack outside the well bore. The same layer of the targeted aquifer

103 is used by another geothermal doublet located $750 \mathrm{~m}$ from DGSY. This doublet has been operated

104 since 2008 without clogging issues.

105 In an attempt to understand the striking difference in sensitivity to clogging over a small 106 distance, a series of interdisciplinary field campaigns was conducted during the spring and summer 107 of 2017. In-situ measurements of physical and chemical characteristics were performed during 108 static conditions and while pumped. The latter used a submersible pump (pumping rate of $16 \mathrm{~m}^{3} / \mathrm{h}$ ) 109 placed above the top of the well screen of the pumping well P1 of DGSY to simulate the normal 110 pumping condition.

112 Well logging. Video camera inspections were performed in each well of DGSY (pumping well 113 P1 and injection well P2), allowing a direct in-situ visualization of clogging deposits. Vertical 114 flowmeter logging was performed during pumping conditions in pumping well $\mathrm{P} 1^{38}$. Flowmeter 115 probes measured vertical movement of water in boreholes and allowed estimation of the 116 permeability distribution along the well borehole ${ }^{39}$. To characterize the groundwater physico117 chemical parameters in static and pumping conditions, multiparameter logs $(\mathrm{pH}$, conductivity, 118 dissolved $\mathrm{O}_{2}(\mathrm{DO})$, Eh and temperature) were performed with a borehole probe in the pumping 
119 well P1. Finally, a heat-pulse flowmeter probe was used to detect presence of vertical flows within

120 pumping well $\mathrm{P} 1$ in static condition ${ }^{40}$.

122 Chemical and metagenomic analysis. Water was sampled in pumping well P1 using a 123 submerged well pump. Water was filtered through a $0.2-\mu \mathrm{m}$ filter on site during sampling. Physico124 chemical properties were obtained by using in-situ multiparameter probes placed in a continuous 125 flow cell supplied by the well pump. Concentrations of major cations and anions, trace-element 126 concentrations, dissolved organic carbon (DOC) and dissolved inorganic carbon (DIC) 127 concentrations were analyzed following protocols described in Pédrot et al. ${ }^{41}$. Total $\mathrm{Fe}_{\text {and }} \mathrm{Fe}^{\mathrm{II}}$ 128 concentrations were measured and showed almost no difference, indicating that Fe is mainly $\mathrm{Fe}^{\mathrm{II}}$.

129 An estimate of the relative abundances of all microorganisms was performed in the pumping well 130 P1, by sampling of three replicates of $5 \mathrm{~L}$ of groundwater in the top and in the bottom of the well 131 and sequencing of the total DNA by MiSeq run (Illumina INC). Analytical methods are detailed 132 in supporting information $\mathbf{S 2}$.

133 Moist encrustations were sampled in April 2017 from the P1 pump riser that had been stored in 134 a warehouse since May 2016. A small quantity of deposits was also sampled from the injection 135 well P2. To characterize sampled deposits, scanning electron microscope (SEM) coupled with 136 energy dispersive x-ray and major and trace-element analyses were performed.

138 Estimation of reactivity induced by mixing through batch experiments. As described in 139 more detail in the Results \& Discussion, two productive zones of chemically heterogeneous water 140 (oxic, zone A and anoxic, zone $\mathrm{H}$ ) were identified in the pumping well $\mathrm{P} 1$ during downhole 141 logging. To quantify chemical reactions induced by mixing of the two types of produced water, 
142 batch incubation experiments using the oxic and anoxic water were conducted. The batch

143 experiment was designed to evaluate homogeneous oxidation kinetics involving native microbes,

144 but excluding previously accumulated sorbents and biofilms that contribute to heterogeneous

145 oxidation processes. Changes in the chemistry of three sets of water samples were evaluated: (1)

146 oxic water from zone A, (2) anoxic water from zone H, and (3) a 50:50 mixture of the oxic and

147 anoxic water. The water for these batch experiments was collected without atmospheric contact by

148 pumping directly from well P1 at levels A and H into autoclaved glass bottles submerged within

149 water-filled buckets. Ten bottles of each water type and the mixture (obtained by pumping from

150 the oxic and anoxic zones simultaneously) were filled and then sealed with a septum while

151 immersed. The sealed samples were incubated at $20^{\circ} \mathrm{C}$ in the laboratory. Over a period of 9 days,

152 one bottle of each series (1 oxic, 1 anoxic and 1 suboxic mixture) was sacrificed daily to measure

$153 \mathrm{pH}, \mathrm{DO}$, and concentrations of major ions and trace elements.

155 Geochemical model. To evaluate potential influences on clogging from various abiotic and

156 biotic kinetic factors, as well as the role of adsorption on the attenuation of $\mathrm{Fe}^{\mathrm{II}}$ and $\mathrm{Mn}^{\mathrm{II}}$, a 157 geochemical model using PHREEQC ${ }^{42}$ was employed. Details of the model construction are given 158 by Cravotta ${ }^{43}$ and summarized in the supporting information S1 and S2. Temperature corrections 159 were automatically applied to constants for aqueous speciation, solubility, and kinetic rate 160 expressions in the geochemical model. The thermodynamic data base, which includes kinetic rate 161 expressions, is available with the model archive file in supporting information S2. The model 162 simulates mixing of the oxic water and anoxic water of specified compositions in proportions 163 pumped and considers kinetics of gas exchange and the oxidation of $\mathrm{Fe}^{\mathrm{II}}, \mathrm{Mn}^{\mathrm{II}}$, and organic carbon 164 for three parallel or sequential steps. For the batch oxidation experiment, parallel reactions are 
165 simulated for three different water samples: (1) oxic; (2) anoxic; and (3) mixed. The parallel model

166 permits evaluation of the batch experiment as conducted, plus consideration of kinetic variables

167 that may be important for more complex systems. For the more complex well clogging application,

168 sequential steps simulate the generalized flow sequence at pumping well P1 of doublet DGSY: (1)

169 gravel pack in annulus; (2) water column inside the well and screen; and (3) water within the pump

170 and riser pipe to the injection head. Heterogeneous oxidation kinetics are computed for adsorbed

$171 \mathrm{Fe}^{\mathrm{II}}$ and $\mathrm{Mn}^{\mathrm{II}}$. The model computes the neutrophilic iron-oxidizing bacteria (FeOB) contribution

172 to $\mathrm{Fe}^{\mathrm{II}}$ oxidation as a function of the $\mathrm{pH}, \mathrm{DO}$, and adsorbed $\mathrm{Fe}^{\mathrm{II}}$.

173

174 RESULTS \& DISCUSSION

175 Characteristics of the clogging deposits. Video revealed clogging deposits covering the inside 176 surface of pumping well P1 from the top down to $33.4 \mathrm{~m}$ (6.54 $\mathrm{m}$ below the top of the well screen).

177 The clogging deposits are reddish brown and became darker brown upward to the top of the well 178 screen, possibly indicating variations in composition. Below $33.4 \mathrm{~m}$, encrustations were not 179 visible. Pumping tests at P1 showed no significant decrease of the well productivity since the first 180 commissioning (initial values of specific capacity and those obtained during our study are $18125 \mathrm{~m}^{3} / \mathrm{h} / \mathrm{m}$ at $20 \mathrm{~m}^{3} / \mathrm{h}$ and $48 \mathrm{~m} / \mathrm{h} / \mathrm{m}$ at $16 \mathrm{~m}^{3} / \mathrm{h}$, respectively). The injection well $\mathrm{P} 2$ also had 182 extensive deposits on the inner surface of the casing and well screen (Figure 1) and strong turbidity 183 in the water column. The video of the injection well showed reddish flocs were easily mobilized 184 from the well surfaces to the water column. 

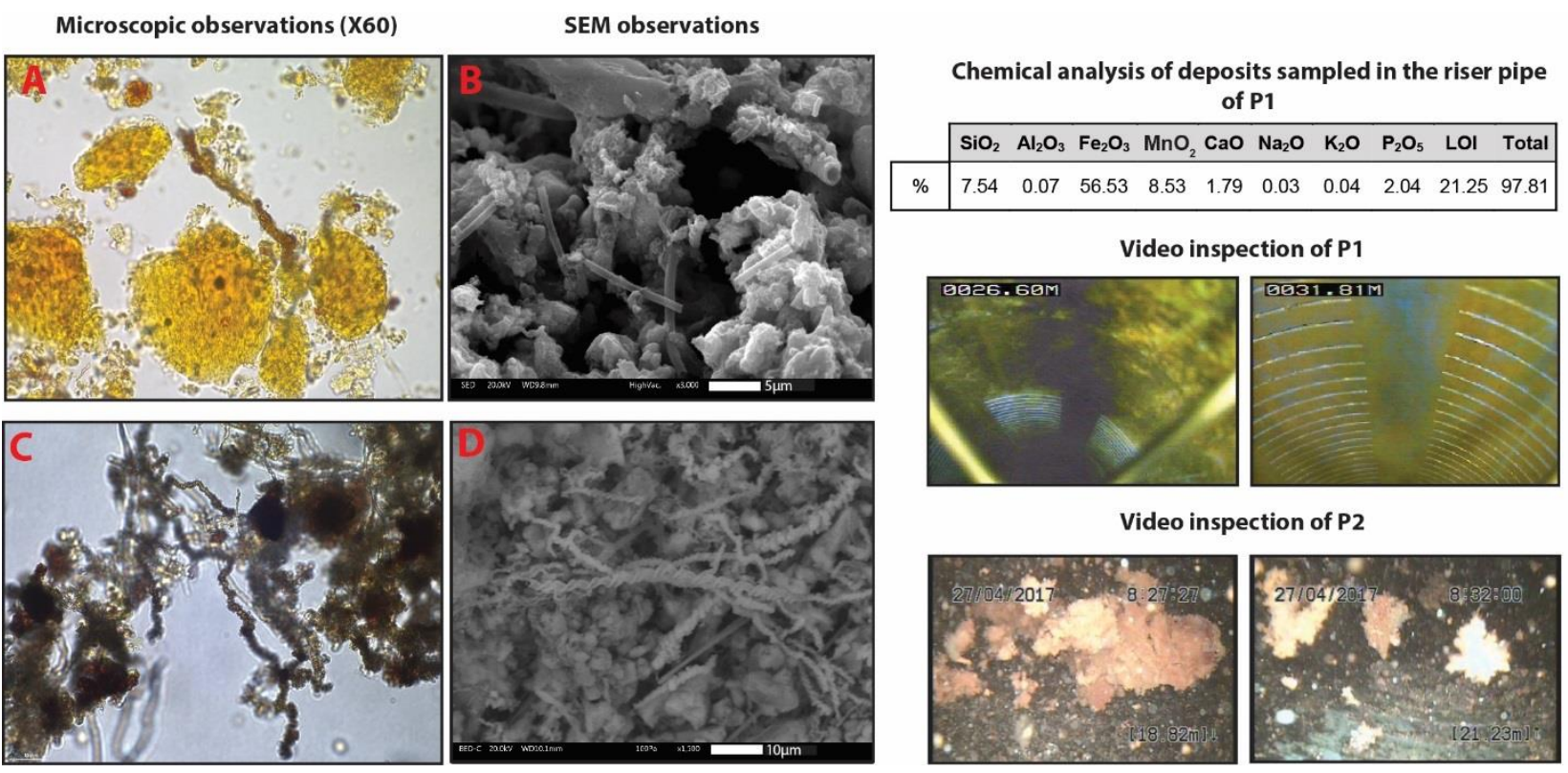

Video inspection of P2

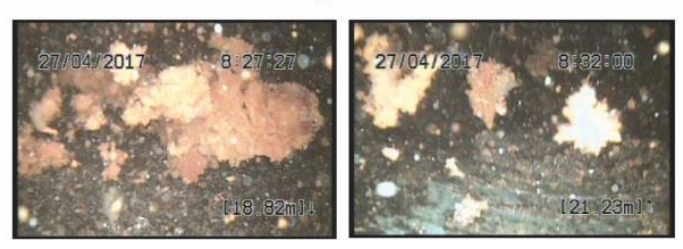

187 Figure 1. Results of microscopic and SEM observations (A - B: deposits from the riser pipe of 188 pumping well P1, C - D : deposits from the injection well P2), chemical analysis of deposits

189 sampled in the riser pipe and pictures from the in -situ video inspection of geothermal doublet

190 DGSY, April 2017.

191 The moist deposits in the riser pipe consisted mainly of iron with smaller amounts of silica and 192 manganese, plus substantial organic carbon and structural water indicated by more than 20 percent

193 weight loss on ignition (LOI) (Figure 1). SEM and microscopic observations indicated the

194 presence of structures characteristic of $\mathrm{FeOB}$ growth (Figure 1): Hollow tubes may indicate

195 Leptothrix sp. ${ }^{44}$; twisted stalks may indicate Gallionella sp. ${ }^{44}$.

197 Physico-chemical characterization of the groundwater at pumping well P1. The flowmeter

198 profile indicated nine productive zones along the well borehole (Figure 2). Two major productive 199 zones, between 26.1 to $27.4 \mathrm{~m}$ (zone A) and between 34.2 and $35.5 \mathrm{~m}$ (zone H) depth below the 200 top of the well screen, represented approximately $27.2 \%$ and $41.1 \%$ of the total flux, respectively, 
201 during pumping. In static conditions (no pumping), heat-pulse flowmeter logs showed a downward 202 flow (between 0.08 and $0.15 \mathrm{~m} / \mathrm{min}$ ) from the top of the well screen to the bottom of the well 203 (exiting at zone I), indicating that the upper permeable zone has a higher hydraulic head than the 204 lower permeable zone.

205 Dissolved oxygen (DO) profiles indicated significant redox heterogeneity (Figure 2). In static 206 conditions, oxic characteristics (DO $1.6-3.3 \mathrm{mg} / \mathrm{L}$ ) predominated above $34.3 \mathrm{~m}$ depth, while 207 anoxic characteristics were detected between 34.3 and $34.5 \mathrm{~m}$ depth, corresponding to the upper 208 part of zone $\mathrm{H}$. The anoxic conditions coincided with the absence of nitrate $(<0.5 \mathrm{mg} / \mathrm{L})$ between 20933 and $35 \mathrm{~m}$ (Figure 2). Hypoxic conditions $(\mathrm{DO}<1.2 \mathrm{mg} / \mathrm{L})$ appeared below zone H. During 210 pumping conditions, major inflows of oxygenated water were identified between 26.5 and $27.5 \mathrm{~m}$ 211 (zone A) and between 28.5 and $29 \mathrm{~m}$ (zone C); however, at greater depths, DO concentrations 212 remained less than $0.2 \mathrm{mg} / \mathrm{L}$. 


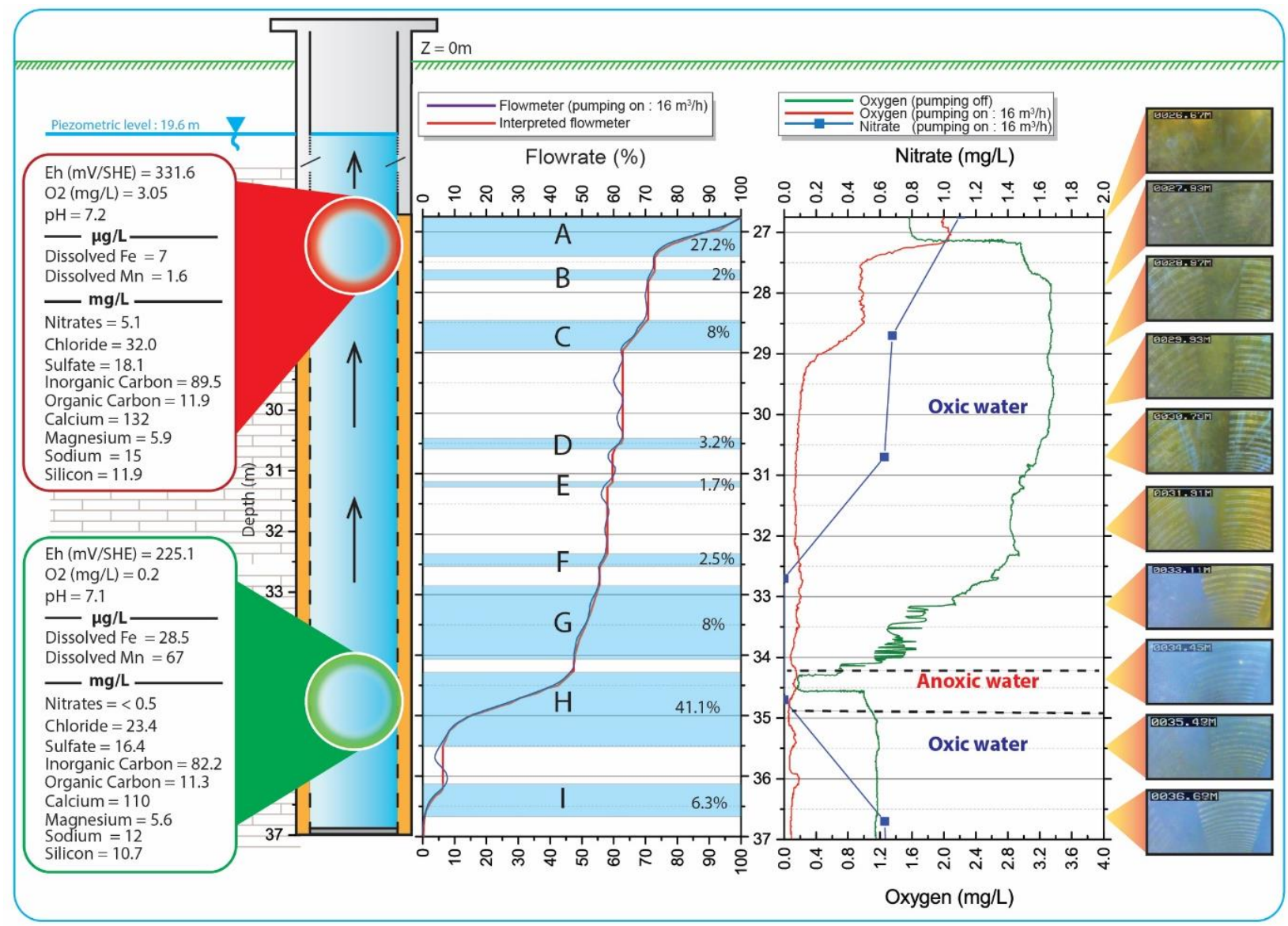

214 Figure 2. Vertical profile of dissolved nitrate (mg/L, pumping condition), dissolved oxygen

215 (mg/L, ambient and pumping condition), flow rate (\%), video image of the pumping well, and

216 summary of chemical characteristics of the groundwater sampled from productive zones A (oxic)

217 and $\mathrm{H}$ (anoxic) in pumping well P1 of doublet DGSY during static conditions, April 2017.

218 Temperature, $12.6^{\circ} \mathrm{C}$, is homogeneous along the well borehole.

219 The profiles of measured concentrations of iron and manganese (pumping condition) showed a

220 maximum near the anoxic zone. Measured concentration of dissolved iron is low compared to

221 previous analysis of total iron performed by the operator at the beginning of the operation

$222(0.1 \mathrm{mg} / \mathrm{L}$ in 2011 and $1.1 \mathrm{mg} / \mathrm{L}$ in 2014). Measured concentrations of other constituents (dynamic 
223 conditions) showed similar vertical heterogeneity along the well screen. Thus, two chemically

224 distinctive waters were identified along the well screens of the pumping well P1 (Figure 2).

225 Metagenomic analyses. The bacteria taxa diversity along the well screen varied vertically 226 (Figure 3). Dominant bacteria of the oxic zone are of the Pseudomonas genus (e.g., Pseudomonas 227 fluorescens, Pseudomonas veronii) (70.75\% of sequences). Globally, the identified bacterial 228 genera in the oxic zone could be involved in manganese oxidation (Pseudomonas fluorescens ${ }^{45}$, 229 Acinetobacter $^{46}$, Janthinobacterium $^{47}$, Variovorax ${ }^{48}$, Caulobacter $^{49}$, Flavobacterium $^{47,50,51}$, 230 Bradyrhizobium $^{52}$ ) and nitrification (Nitrospira, Nitrospina). Communities of the anoxic zone 231 (Figure 3) are dominated by Sphingomonadaceae ${ }^{53}$ (Novosphingobium, Sphingobium, 232 Sphingopyxis and Sphingomonas genera), especially known for degradation of polycyclic aromatic 233 hydrocarbons ${ }^{54,55}$. Iron reducing bacteria (FeRB) (Rhodoferax, Geothrix) are also detected in this 234 zone, as well as Nitrospira and Nitrospina genera. Moreover, despite the observation by electron 235 microscopy of characteristic structures of the best known $\mathrm{FeOB}$, belonging to the Gallionellaceae 236 family (e.g., Gallionella ferruginea) and the Leptothrix genus (e.g., Leptothrix ochracea, 237 Leptothrix discophora) in the biofilm, sequences of these bacteria were not found at the two water 238 sampling points in the well. The metagenomics analysis reveals the microbial diversity of the two 239 main water bodies whose mixing induces clogging when operating the geothermal system. While 240 the bacteria involved in clogging process are naturally present in the aquifer, their relative 241 abundance is likely to be modified during the clogging process. 


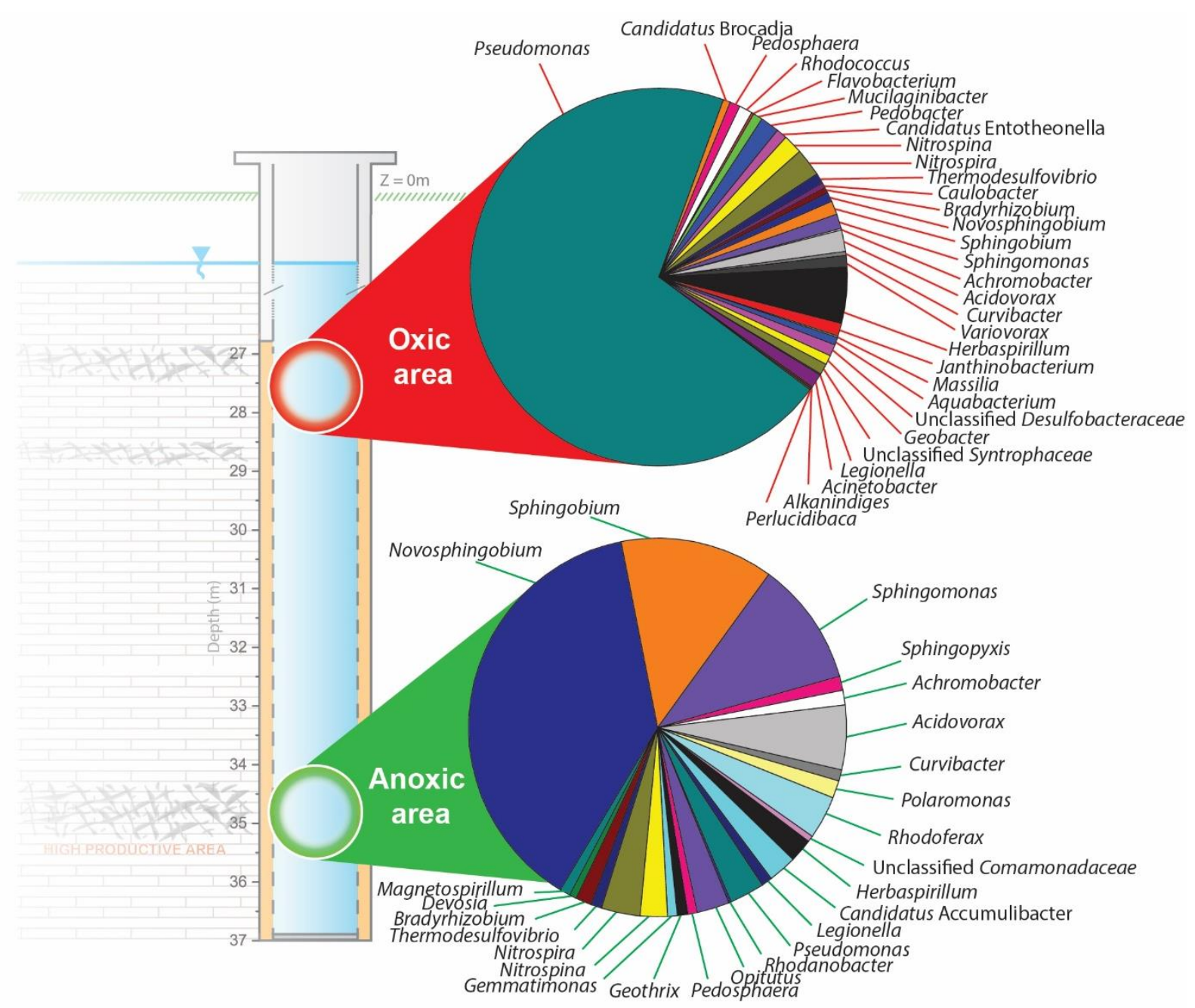

243 Figure 3. Relative abundances of bacterial genera present in the groundwater along the well

244 screens of P1, April 2017. 

information) show the observed changes in chemical concentrations of the oxic water, the anoxic water, and the mixed water extracted from pumping well P1 into sealed glass bottles and then monitored daily for 9 days in July 2017. Dissolved manganese concentrations were relatively stable within each series. In contrast, dissolved iron decreased to concentrations below detection and, therefore, is assumed to have been completely oxidized for the mixed water and oxic water.

253 Concentrations of oxygen, nitrate, and dissolved organic carbon decreased in all three samples as

254 shown in Figure SI.4 (supporting information).
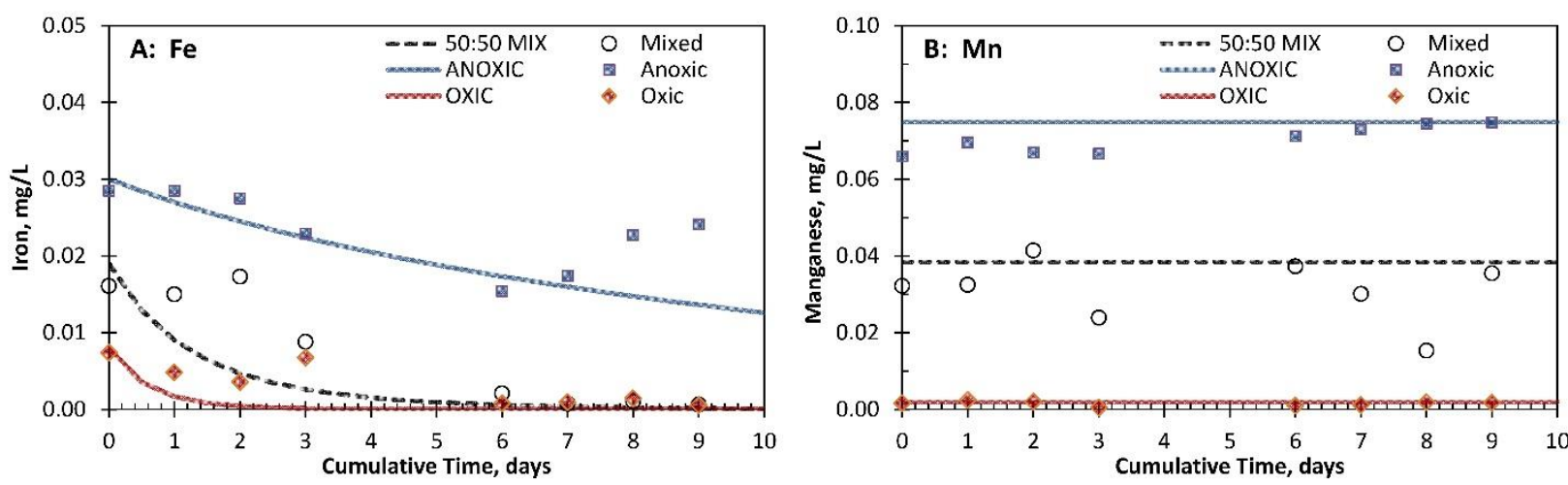

256 Figure 4. Time series of measured data (points) and PHREEQC simulation (lines) of chemical

257 changes to oxic water, anoxic water, and suboxic water resulting from a 50:50 mixture from

258 pumping well P1 for batch experiment.

259 Geochemical modeling of reactive mixing process. Figure 4 shows the model results (curves)

260 compared to the empirical, batch mixing data (points). To simulate the suboxic mixed conditions,

261 the oxic and anoxic waters were mixed in equal proportions (50:50), and the only sorbent

262 considered was that produced by the oxidation and precipitation of initially aqueous $\mathrm{Fe}^{\mathrm{II}}$ and $\mathrm{Mn}^{\mathrm{II}}$

263 (autocatalytic oxidation). The model for the batch experiments demonstrates that the homogeneous

$264 \mathrm{Fe}^{\mathrm{II}}$ oxidation rate law ${ }^{56}$, with adjustment for organic complexation of dissolved Fe, can account 
265 for the observed $\mathrm{Fe}^{\mathrm{II}}$ oxidation. Organic complexation of aqueous $\mathrm{Fe}^{\mathrm{II}}$ and $\mathrm{Fe}^{\mathrm{III}}$ by $1.5 \mathrm{mg} / \mathrm{L}$ humate

266 slows down the simulated reaction rate by a factor 0.01 , which is consistent with observed rates.

267 Such organic complexation may result from naturally occurring organics, but probably results from

268 locally elevated concentrations of manmade organic compounds (11-12 mg/L of uncharacterized

269 DOC) at doublet DGSY as discussed below.

270 Figure 5 shows the results for simulations of sequential kinetic reactions within the pumping well 271 system of the geothermal loop that could explain the rapid accumulation of clogging deposits 272 during the 5-minute residence time. For these simulations, the proportion of oxic water and anoxic 273 water was based on flowmeter measurements (respectively 59\% and $41 \%$ ). In contrast to the batch

274 mixing experiment, where the only sorbent considered is that produced by abiotic plus biotic 275 kinetic oxidation of dissolved $\mathrm{Fe}^{\mathrm{II}}$ and $\mathrm{Mn}^{\mathrm{II}}$; the in-situ simulations consider added sorbent and 276 show potential effects on attenuation of $\mathrm{Fe}^{\mathrm{II}}$ and $\mathrm{Mn}^{\mathrm{II}}$ by accumulated hydrous ferric oxide (HFO) 277 and hydrous manganese oxide (HMO), plus catalytic activity by FeOB. For both scenarios shown 278 in Figure 5, the amount of sorbent in the gravel pack was computed for a thickness of $0.01 \mu \mathrm{m}$, 279 whereas that on well and pump was computed for a thickness of $1.0 \mu \mathrm{m}$. The accumulations inside 280 the well column and pump were as thick as $0.01 \mathrm{~m}$ (Figure SI.1 in supporting information); 281 however, only a small fraction of that thickness $(1.0 \mu \mathrm{m})$ is assumed to be in contact with water 282 for surface reactions. Furthermore, the coating on the gravel pack was assumed to be $100 \%$ HFO 283 (Fe), whereas that on the well and pump was 97.0\% HFO, 2.9\% HMO, and 0.1\% hydrous 284 aluminum oxide (HAO). Simulation results for the default FeOB oxidation rate (1X) (Figures. 285 5A-5B) produce the observed "biofouling" with iron-rich solids; increasing the FeOB oxidation 286 rate by a factor of $10(10 \mathrm{X})$ greatly increases the accumulation of precipitate (Figures. 5C-5D). 287 Additional simulation results shown as Figure SI.5A-5J (supporting information) demonstrate the 
288 effects of different initial coatings (distribution and composition) as well as microbial catalysis 289 (FeOB rates of 0X, 1X, and 10X) on $\mathrm{Fe}^{\mathrm{II}}$ and $\mathrm{Mn}^{\mathrm{II}}$ attenuation.
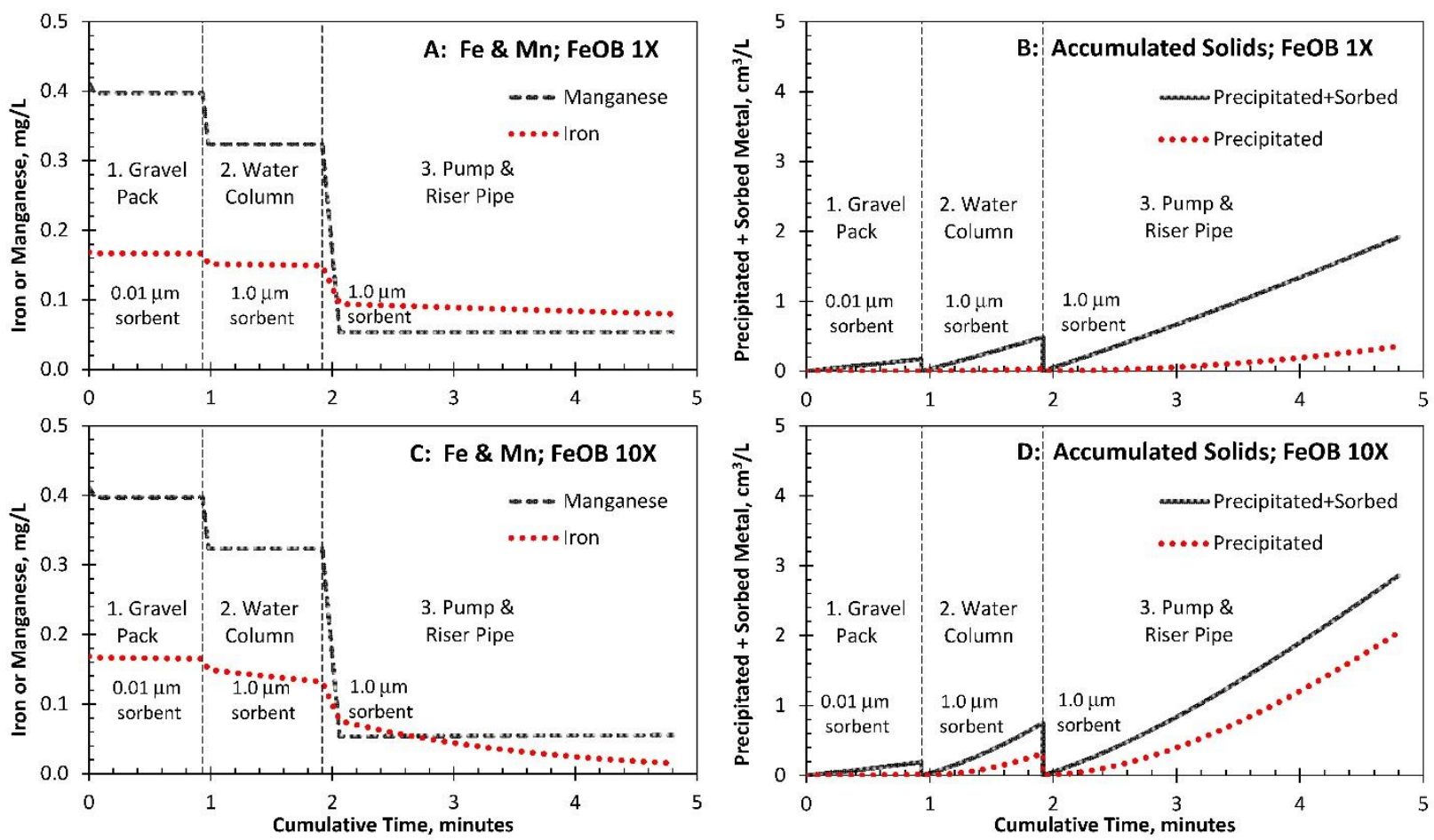

291 Figure 5. PHREEQC simulation of changes in dissolved $\mathrm{Fe}^{\mathrm{II}}$ and $\mathrm{Mn}^{\mathrm{II}}$ concentrations in mixed

292 oxic (59\%) and anoxic (41\%) water and the consequent volume of precipitated+adsorbed metals

293 produced by sequential kinetic and equilibrium speciation reactions in gravel pack, water column,

294 and pump+riser pipe of geothermal loop pumping well P1. Results shown consider previously

295 accumulated sorbent of varied mass (thickness $0.01 \mu \mathrm{m}$ in gravel pack and $1.0 \mu \mathrm{m}$ in well and 296 pump+riser) and composition (100\% HFO in gravel pack, and 97.0\% HFO, 2.9\% HMO, and 0.1\%

297 HAO in well and pump+riser) plus autocatalytic sorbent: A-B, default (1X) FeOB rate; C-D, 298 enhanced (10X) FeOB rate.

Biogeochemical processes at the origin of clogging. Our investigations showed that doublet 
302 communities in the oxic and anoxic groundwater (Figure 3). In the anoxic zone, communities are

303 dominated by Novosphingobium, Sphingobium, Sphingomonas genera, which do not appear in the

304 oxic zones. Such communities are involved in the degradation of polycyclic aromatic

305 hydrocarbons (PAHs) $)^{24,57,58}$. Thus, the anoxic conditions could result from oxygen consumption

306 during bio-oxidation of PAHs that causes the release of dissolved metals from aquifer materials

307 by reductive dissolution. Although no DOC distinction was observed between zone $\mathrm{H}$ and other

308 zones, the DOC concentrations were assumed to be remnant of previous oxidation of organic

309 pollutants. SEM analysis and microscopic observations of the deposits from the well pump indicate

310 structures associated with FeOB (iron twisted stalks and iron hollow tubes; Figure 1). However,

311 Gallionella, Ferriphaselus and Leptothrix genera were not identified in water samples collected

312 along the well screen. This implies that biological structures in the clogging deposits may result

313 from the activity of different FeOB (i.e. other Comamonadaceae ${ }^{59}$ than the known Leptothrix

314 bacteria, nitrate-dependent FeOB, or unidentified genera whose genome is not yet referenced), or

315 the water samples may not represent the entire microbial community within biofilms on the well

316 surfaces. Regardless, the positive identification of genera related to iron and manganese oxidation

317 confirms that biological processes are probably involved in clogging processes. Further, once

318 oxidized, $\mathrm{Fe}^{\mathrm{III}}$ (as HFO) and $\mathrm{Mn}^{\mathrm{III}-\mathrm{IV}}$ (as HMO) may then serve as terminal electron acceptors for

319 FeRB that decompose organic molecules. Sulfate-reducing bacteria (SRB) were observed at a low

320 abundance that may indicate an insignificant contribution to the chemical processes. Although

321 SRB activities have been reported in geothermal wells, redox levels in pumping well P1 were

322 relatively high compared to other geothermal systems. 
324 Mass balance of clogging deposits. The rapid clogging observed during 2011 operations 325 indicates a massive and rapid accumulation of the oxide deposit. We estimated a hypothetical 326 concentration of dissolved iron that could explain the rapid clogging based on the deposit 327 distribution in the water system and the total recorded volume of water pumped since the beginning 328 of operation. Observations of the pump column show a thickness of deposit of about $0.01 \mathrm{~m}$. 329 Assuming a constant thickness along the water system between the submerged well pump of P1 330 and the injection well $\mathrm{P} 2$, the estimated volume of clogging deposits is about $0.245 \mathrm{~m}^{3}$. Note that 331 this assumption does not consider the amount of deposits that may have precipitated within the 332 well bore and gravel pack, nor the mobilized deposits that clogged the filter or that had been 333 transported into the injection well P2. Chemical analysis (Figure 1) indicates that the dry deposit 334 is composed of $56.5 \% \mathrm{Fe}_{2} \mathrm{O}_{3}$ or $75.7 \%$ as $\mathrm{Fe}(\mathrm{OH})_{3}$. Taking a bulk density of hydrous ferrous 335 oxide ${ }^{57}$ of $1.25 \mathrm{~g} / \mathrm{cm}^{3}$, the computed $\mathrm{Fe}^{2+}$ concentrations are approximately $0.37 \mathrm{mg} / \mathrm{L}$, which is 33612 times higher than measured concentrations in 2017 (Figure 2), but comparable to the 337 concentrations ( 0.1 to $1.1 \mathrm{mg} / \mathrm{L}$ ) reported by the operator at the beginning of operations in 2011 . 338 This result indicates that the chemical conditions in the aquifer could have evolved since 2011. In 339 unconfined aquifers, concentrations of chemical species, including redox active species, have 340 seasonal variations linked to recharge or discharge. Evidence of ambient downward vertical flow 341 (infiltration of oxic groundwater from oxic zone to the underlying anoxic zone) was found within 342 the pumping well during static conditions. Since the shutdown of the installation (May 2016), the 343 invasion of oxic water may have caused a progressive oxidation of dissolved iron in the aquifer 344 near the well. Hence, the chemical characteristics of the groundwater extracted from the anoxic 345 zone during our study may differ from the initial conditions of the thermal pump operation in 2011. 
Location of clogging processes. Video inspection of the pumping well shows extensive reddish-

348 brown deposits in the upper part of the well and a lack of visible deposits in the anoxic zone. The

349 visible deposits occurred from the piezometric surface at $19.6 \mathrm{~m}$ depth to the top of the anoxic

350 zone at $33.4 \mathrm{~m}$ depth (Figure 2). Thus, clogging deposits appear to develop from the beginning of

351 the geothermal loop where the aqueous $\mathrm{Fe}^{\mathrm{II}}$ and $\mathrm{Mn}^{\mathrm{II}}$ in the anoxic water mix with the oxic water

352 during pumping. Presence of this clogging material along the geothermal loop (piping, filter,

353 exchanger and injection well) can be explained by the transport of aqueous and solid forms of Fe

354 and Mn along the flow path, with consequent interactions, explained below.

356 Geochemical modeling of the development of clogging deposits. The batch mixing

357 experiment demonstrated that mixing of anoxic and oxic waters from the well resulted in more

358 rapid and extensive $\mathrm{Fe}^{\mathrm{II}}$ oxidation than achieved by solely the anoxic and oxic waters, while little

359 if any $\mathrm{Mn}^{\mathrm{II}}$ is attenuated (Figure 4). For the simulation of the batch experiment, the only sorbent

360 was that formed by the in-situ oxidation of the initial $\mathrm{Fe}^{\mathrm{II}}(0.03 \mathrm{mg} / \mathrm{L}$ and $0.008 \mathrm{mg} / \mathrm{L})$ and $\mathrm{Mn}^{\mathrm{II}}$

$361(0.075$ and $0.002 \mathrm{mg} / \mathrm{L})$ in the anoxic and oxic water, respectively. Complexing by $1.5 \mathrm{mg} / \mathrm{L}$

362 humate was considered to explain the slow rates of $\mathrm{Fe}^{\mathrm{II}}$ oxidation. A concentration of $1.5 \mathrm{mg} / \mathrm{L}$

363 humate corresponds to approximately $6.5 \%$ of the measured, but uncharacterized DOC (11-12

$364 \mathrm{mg} / \mathrm{L}$ ) (Figure 2). Humate in the model may be considered a surrogate for natural organic matter

365 (NOM) and manmade organic compounds that have varying capacities to form metal-organic

366 complexes ${ }^{60,61}$. NOM contains between $40 \%$ and $60 \% \mathrm{C}$ (fulvic acid $40 \%$ to $50 \%$ and humic acid

$36750 \%$ to $60 \%$ ), whereas organic molecules of manmade origin have wide ranges in concentration

368 of C (tetrachlorethylene 15\% C to PAH 90\% C). Rose and Waite $(2003)^{60}$ reported that Fe ${ }^{\mathrm{II}}-\mathrm{NOM}$

369 complex formation occurs on a similar time scale as $\mathrm{Fe}^{\mathrm{II}}$ oxidation. Chen and Thompson $(2018)^{61}$ 
370 demonstrated that complexation by natural organic acid substantially retarded $\mathrm{Fe}^{\mathrm{II}}$ oxidation at $1 \%$

$371 \mathrm{O}_{2}$, but had a negligible effect at $21 \% \mathrm{O}_{2}$. Without the simulated organic complexation of dissolved

372 iron, the model predicted complete $\mathrm{Fe}^{\mathrm{II}}$ attenuation from the mixed water within 24 hours.

373 The model simulating the mixing and sequential reactions in the pumping well (1) uses an initial

374 concentration of $0.4 \mathrm{mg} / \mathrm{L} \mathrm{Fe}^{\mathrm{II}}$ in the anoxic water, consistent with the mass-balance computations,

375 and (2) indicates that a rapid rate of chemical change, consistent with clogging observations, can

376 take place primarily where previously accumulated HFO and HMO are available for reaction

377 (Figure 5). Initial simulations indicate that simple mixing combined with homogeneous

378 (autocatalytic) $\mathrm{Fe}^{\mathrm{II}}$ oxidation, including microbial catalysis, has a negligible effect on $\mathrm{Fe}^{\mathrm{II}}$ and $\mathrm{Mn}^{\mathrm{II}}$

379 attenuation during the few minutes that water is retained in the well and pumping system (Figure

380 SI.5A-5B). In this case, the reaction time for kinetic oxidation of $\mathrm{Fe}^{\mathrm{II}}$ and $\mathrm{Mn}^{\mathrm{II}}$ increases with

381 distance from the mixing zone, favoring the accumulation of the precipitate further along the flow

382 path between the pumping and injection wells. Such a simulation may mimic the early conditions

383 in doublet DGSY. However, as the clogging deposit accumulated over time, the material began to

384 function as an effective sorbent, catalyst for heterogeneous $\mathrm{Fe}^{\mathrm{II}}$ and $\mathrm{Mn}^{\mathrm{II}}$ oxidation, and substrate

385 for microbial growth, all of which facilitated faster and more extensive accumulation of the oxide

386 deposits (Figures SI.5C-5J).

387 The simulations show that if a uniform mass of HFO per liter of water is present throughout the 388 gravel pack, well bore, and pump, most of the $\mathrm{Fe}^{\mathrm{II}}$ and $\mathrm{Mn}^{\mathrm{II}}$ removal takes place by adsorption 389 processes within the gravel pack, which has a large surface area (Figures SI.5C-5D). However, 390 based on our observations, the deposits were more extensive within the upper part of the well, 391 pump, and riser pipe, and the observed materials contained a mixture of HFO and HMO. The 392 simulation results shown in Figures 5A-5D (also shown as Figures SI.5G-5J) considered a 0.01X 
393 smaller mass of sorbent in the gravel pack $(0.01 \mu \mathrm{m}$ thick, where mixing and oxidation are

394 negligible) compared to that within the well and pump (1.0 $\mu \mathrm{m}$ thick, where mixing and oxidation

395 take place), plus variable composition of sorbent (100\% HFO in gravel pack; 97.0\% HFO, 2.9\%

$396 \mathrm{HMO}$, and 0.1\% HAO inside well and pump) combined with FeOB activity. Results for the

397 simulations with this heterogeneous sorbent distribution and composition and considering the

398 enhanced (10X) FeOB rate (Figures 5C-5D or SI.5I-5J) are consistent with the observed

399 biofouling of the pump and riser pipe and demonstrate that accumulated deposits within the upper

400 part of the well system combined with microbial catalysis can have a dramatic effect on attenuation

401 of $\mathrm{Fe}^{\mathrm{II}}$ and $\mathrm{Mn}^{\mathrm{II}}$ in that zone. It should be noted that the model default FeOB rate contribution (1X)

402 is an average factor of 20 times the abiotic heterogeneous $\mathrm{Fe}^{\mathrm{II}}$ oxidation rate under optimum

403 conditions of near-neutral $\mathrm{pH}(6.5-7.5)$ and low DO (1.9-2.2 $\left.\mathrm{mg} \mathrm{L}^{-1}\right)$, whereas the enhanced rate

$404(10 \mathrm{X})$ modeled is near the maximum FeOB rate reported for those conditions ${ }^{35}$.

405 Increasing the percentage of HMO in the sorbent increases the attenuation of $\mathrm{Mn}^{\mathrm{II}}$. Because the

406 clogging material was heterogeneous, with the black (HMO) deposits overlain by reddish (HFO)

407 deposits, the simulations shown in Figures 5A-5D (and Figures SI.5E-5J) considered a lesser

408 amount of $\mathrm{HMO}$ in the surface layer $(97.0 \% \mathrm{Fe}, 2.9 \% \mathrm{Mn}$, and $0.1 \% \mathrm{Al})$ exposed to the

409 groundwater compared to the content reported for the riser pipe $(87.93 \% \mathrm{Fe}, 11.99 \% \mathrm{Mn}$, and

$410 \quad 0.08 \% \mathrm{Al}$, expressed as the metals) (Figure 1). Simulations for a sorbent with that high HMO

411 content resulted in complete removal of dissolved $\mathrm{Mn}^{\mathrm{II}}$, which is inconsistent with observations.

412 The batch incubation experiments and geochemical kinetics models indicate that the rates of 413 homogeneous and heterogeneous $\mathrm{Fe}^{\mathrm{II}}$ oxidation are relatively slow and inefficient at observed

414 near-neutral $\mathrm{pH}$ compared to the short residence time of water in the well bore and gravel pack, 415 even considering microbial catalysis. However, the field observations and modeling of in-situ 
416 mixing and oxidation processes indicate that accumulated HFO, HMO, and biofilm on surfaces

417 within the pump and riser pipe, the well bore, and, to a lesser extent, the surrounding gravel pack

418 effectively bind $\mathrm{Fe}^{\mathrm{II}}$ and $\mathrm{Mn}^{\mathrm{II}}$. The adsorbed metals have infinite time for oxidation and provide a

419 convenient source of energy for FeOB that attach to the surfaces. For the modeled conditions

420 within the well, concentrations of dissolved $\mathrm{Fe}^{\mathrm{II}}$ were low compared to the accumulated HFO

421 sorbent surface area. Despite continuous Fe $\mathrm{Fe}^{\mathrm{II}}$ adsorption, microbial oxidation of aqueous and

422 (accumulated) adsorbed $\mathrm{Fe}^{\mathrm{II}}$ replenishes the HFO sorbent. The metagenomics data indicate diverse

423 microbial taxa and heterogeneous conditions in the aquifer; various organisms identified in oxic

424 and anoxic zones could catalyze redox processes. The coupled adsorption and bio-oxidation

425 processes facilitated by mixing of oxic and anoxic waters promote accumulation of $\mathrm{Fe}^{\mathrm{III}}-\mathrm{Mn}^{\mathrm{III}-\mathrm{IV}}$

426 precipitate and can thus trigger rapid clogging of pumping wells, despite relatively low

427 concentrations of dissolved oxygen, $\mathrm{Fe}^{\mathrm{II}}$ and $\mathrm{Mn}^{\mathrm{II}}$ and short retention times of the groundwater in

428 the well and plumbing system. In addition to restricting flow through the zone of accumulation,

429 scour and transport of precipitated solids could explain rapid clogging of the filter at the heat

430 exchanger within a few hours after a restarting of pumping.

431 The physical and biogeochemical reaction mechanisms described in this study may have a broad

432 relevance for groundwater extraction systems where pumping induces mixing of oxic $\left(\mathrm{O}_{2} / \mathrm{NO}_{3}\right.$

433 rich) and anoxic $\left(\mathrm{Fe}^{\mathrm{II}} / \mathrm{Mn}^{\mathrm{II}}\right.$ rich) groundwaters or introduces oxygenated air into the pumped water.

434 To identify the risk and predict the appearance of clogging processes linked to $\mathrm{Fe}^{\mathrm{II}}$ and $\mathrm{Mn}^{\mathrm{II}}$ bio-

435 oxidation, the hydraulic and chemical heterogeneity within the well should be characterized under

436 static and pumping conditions at the start of shallow geothermal projects. In conventional

437 geothermal system design, the feasibility of a geothermal operation is based on the chemical

438 analysis of one water sample obtained at the end of a pumping test. Instead, a depth-oriented 
439 sampling strategy, including in-situ water-quality logging, is warranted for identification of 440 potentially oxidizing and reducing conditions along the well screen. In-situ characterization during 441 ambient and dynamic conditions (coupled with flowmeter measurement) is necessary as the 442 chemical signature of the water column inside the well is controlled by natural and induced fluxes.

443 The initial precipitation of HFO and HMO deposits exacerbates additional accumulations, which

444 implies a need for frequent rehabilitation procedures to avoid clogging. The intentional removal 445 of deposits from the pumping well could involve a combination of physical and chemical 446 applications. Adapted preventive methods (automatic back-washing filter, injection well equipped 447 with back-washing pump) could be considered. In situations where clogging risk is significant, 448 closed loop geothermal systems may be considered as an alternative to the open loop doublets.

\section{ACKNOWLEDGMENTS}

451 The authors thank managers of the studied geothermal doublet for granting permission to 452 investigate the clogging phenomena and publish our results. This work was conducted as part of 453 the research project "GEOCLOGGING," which has been funded by the French Environment and 454 Energy Management Agency (ADEME). We are grateful to Biogenouest Genomics and the 455 Human \& Environmental Genomics core facility of Rennes (Biosit/OSUR), especially Marine 456 Biget and Sophie Michon-Coudouel, for the technical support concerning the metagenome 457 sequencing. Helpful reviews of an early draft of the manuscript were provided by Dr. Oliver Opel 458 of West Coast University of Applied Sciences, Fachbereich Technik, Heide Germany, and 459 anonymous journal referees. Any use of trade, firm, or product names is for descriptive purposes 460 only and does not imply endorsement by the U.S. Government. 
Two files of supporting information (Word document and zip file) are offered. SIl provides additional details on the characteristics of geothermal doublets DGSY, materials and methods (chemical and metagenomic analyses), and geochemical model development and application.

466 Figures depicting results of geochemical simulations are also included. The model archive is 467 available as a zip file, which includes the executable programs (parallel and sequential models), 468 thermodynamic data base with rate expressions, and Excel files that summarize the simulation 469 results and display the graphics used for figures in the main text and SI1.

\section{REFERENCES CITED}

(1) Famework Convention on Climate Change, United Nations. Report of the Conference of the Parties on Its Twenty-First Session, Held in Paris from 30 November to 13 December 2015, Addendum Part Two: Action Taken by the Conference of the Parties at Its Twenty-First Session; FCCC/CP/2015/10/Add.1; 2016.

(2) Possemiers, M.; Huysmans, M.; Anibas, C.; Batelaan, O.; Van Steenwinkel, J. Reactive Transport Modeling of Redox Processes to Assess $\mathrm{Fe}(\mathrm{OH}) 3$ Precipitation around Aquifer Thermal Energy Storage Wells in Phreatic Aquifers. Environ. Earth Sci. 2016, 75 (8), 648. https://doi.org/10.1007/s12665-016-5398-7.

(3) García-Gil, A.; Epting, J.; Ayora, C.; Garrido, E.; Vázquez-Suñé, E.; Huggenberger, P.; Gimenez, A. C. A Reactive Transport Model for the Quantification of Risks Induced by Groundwater Heat Pump Systems in Urban Aquifers. J. Hydrol. 2016, 542, 719-730. https://doi.org/10.1016/j.jhydrol.2016.09.042.

(4) Schneider, E. A. G.; García-Gil, A.; Vázquez-Suñè, E.; Sánchez-Navarro, J. Á. Geochemical Impacts of Groundwater Heat Pump Systems in an Urban Alluvial Aquifer with Evaporitic Bedrock. Sci. Total Environ. 2016, 544, 354-368. https://doi.org/https://doi.org/10.1016/j.scitotenv.2015.11.096.

(5) Hähnlein, S.; Bayer, P.; Ferguson, G.; Blum, P. Sustainability and Policy for the Thermal Use of Shallow Geothermal Energy. Energy Policy 2013, 59, 914-925. https://doi.org/https://doi.org/10.1016/j.enpol.2013.04.040.

(6) Gino, E.; Starosvetsky, J.; Kurzbaum, E.; Armon, R. Combined Chemical-Biological Treatment for Prevention/Rehabilitation of Clogged Wells by an Iron-Oxidizing Bacterium. Environ. Sci. Technol. 2010, 44 (8), 3123-3129. https://doi.org/10.1021/es903703v.

(7) Saripalli, K. P.; Meyer, P. D.; Bacon, D. H.; Freedman, V. L. Changes in Hydrologic Properties of Aquifer Media Due to Chemical Reactions: A Review. Crit. Rev. Environ. Sci. Technol. 2001, 31 (4), 311-349. https://doi.org/10.1080/20016491089244. 
(8) Hand, V. L.; Lloyd, J. R.; Vaughan, D. J.; Wilkins, M. J.; Boult, S. Experimental Studies of the Influence of Grain Size, Oxygen Availability and Organic Carbon Availability on Bioclogging in Porous Media. Environ. Sci. Technol. 2008, 42 (5), 1485-1491. https://doi.org/10.1021/es072022s.

(9) Bonte, M.; Röling, W. F. M.; Zaura, E.; van der Wielen, P. W. J. J.; Stuyfzand, P. J.; van Breukelen, B. M. Impacts of Shallow Geothermal Energy Production on Redox Processes and Microbial Communities. Environ. Sci. Technol. 2013, 47 (24), 14476-14484. https://doi.org/10.1021/es4030244.

(10) Bustos Medina, D. A.; van den Berg, G. A.; van Breukelen, B. M.; Juhasz-Holterman, M.; Stuyfzand, P. J. Iron-Hydroxide Clogging of Public Supply Wells Receiving Artificial Recharge: Near-Well and in-Well Hydrological and Hydrochemical Observations. Hydrogeol. J. 2013, 21 (7), 1393-1412. https://doi.org/10.1007/s10040-013-1005-0.

(11) Houben, G. J. Iron Oxide Incrustations in Wells. Part 1: Genesis, Mineralogy and Geochemistry. Appl. Geochem. 2003, 18 (6), 927-939. https://doi.org/10.1016/S08832927(02)00242-1.

(12) van Beek, C. G. E. M.; Hubeek, A. A.; de la Loma Gonzalez, B.; Stuyfzand, P. J. Chemical and Mechanical Clogging of Groundwater Abstraction Wells at Well Field Heel, the Netherlands. Hydrogeol. J. 2017, 25 (1), 67-78. https://doi.org/10.1007/s10040-016-14699.

(13) Martin R. Clogging Issues Associated with Managed Aquifer Recharge Methods. Russel Martin (ed.) 2013.

(14) Brown, C. J.; Misut, P. E. Aquifer Geochemistry at Potential Aquifer Storage and Recovery Sites in Coastal Plain Aquifers in the New York City Area, USA. Appl. Geochem. 2010, 25 (9), 1431-1452. https://doi.org/10.1016/j.apgeochem.2010.07.001.

(15) Wang, J.; Sickinger, M.; Ciobota, V.; Herrmann, M.; Rasch, H.; Rösch, P.; Popp, J.; Küsel, K. Revealing the Microbial Community Structure of Clogging Materials in Dewatering Wells Differing in Physico-Chemical Parameters in an Open-Cast Mining Area. Water Res. 2014, 63, 222-233. https://doi.org/10.1016/j.watres.2014.06.021.

(16) Weidner, C.; Henkel, S.; Lorke, S.; Rüde, T. R.; Schüttrumpf, H.; Klauder, W. Experimental Modelling of Chemical Clogging Processes in Dewatering Wells. Mine Water Environ. 2012, 31 (4), 242-251. https://doi.org/10.1007/s10230-012-0188-2.

(17) Georg Houben; Christoph Treskatis. Water Well Rehabilitation and Reconstruction; McGraw Hill Professional, Access Engineering, 2007.

(18) Cullimore, R. Microbiology of Well Biofouling, 1st Edition.; CRC press, 1999.

(19) Alford, G.; Cullimore, R. The Application of Heat and Chemicals in the Control of Biofouling Events in Wells, 1st Edition.; CRC press, 1998.

(20) Bonte, M.; Wols, B.; Maas, K.; Stuyfzand, P. Sources of Dissolved Oxygen in Monitoring and Pumping Wells. Hydrogeol. J. 2017, 25 (1), 55-66. https://doi.org/10.1007/s10040016-1477-9.

(21) Schnieders, J. Well Blockage and Rehabilitation. In Sterret, RJ (ed) Groundwater and wells; Johnson Screens: New Brighton MN, 2007; pp 597-628.

(22) Driscoll, F. . Well and Pump Maintenance and Rehabilitation. In Groundwater and wells; Johnson Screens: St. Paul MN, 1986; pp 630-669.

(23) Eggerichs, T.; Otte, T.; Opel, O.; Ruck, W. K. L. Direct and Mn-Controlled Indirect Iron Oxidation by Leptothrix Discophora SS-1 and Leptothrix Cholodnii. Geomicrobiol. J. 2015, 32 (10), 934-943. https://doi.org/10.1080/01490451.2015.1039671. 
(24) Appelo C. A. J.; Postma D. Geochemistry, Groundwater and Pollution (2nd); A.A. Balkema Publishers: Leiden, The Netherlands, 2005.

(25) Menz, C. Oxygen Delivering Processes in Groundwater and Their Relevance for IronRelated Well Clogging Processes-a Case Study on the Quaternary Aquifers of Berlin, Freie Universität Berlin, 2016.

(26) Farnsworth, C. E.; Voegelin, A.; Hering, J. G. Manganese Oxidation Induced by Water Table Fluctuations in a Sand Column. Environ. Sci. Technol. 2012, 46 (1), 277-284. https://doi.org/10.1021/es2027828.

(27) Kohfahl, C.; Massmann, G.; Pekdeger, A. Sources of Oxygen Flux in Groundwater during Induced Bank Filtration at a Site in Berlin, Germany. Hydrogeol. J. 2008, 17 (3), 571. https://doi.org/10.1007/s10040-008-0389-8.

(28) Williams, M. D.; Oostrom, M. Oxygenation of Anoxic Water in a Fluctuating Water Table System: An Experimental and Numerical Study. J. Hydrol. 2000, 230 (1), 70-85.

(29) Jia, M.; Bian, X.; Yuan, S. Production of Hydroxyl Radicals from Fe(II) Oxygenation Induced by Groundwater Table Fluctuations in a Sand Column. Sci. Total Environ. 2017, 584, 41-47. https://doi.org/10.1016/j.scitotenv.2017.01.142.

(30) Holocher, J.; Peeters, F.; Aeschbach-Hertig, W.; Kinzelbach, W.; Kipfer, R. Kinetic Model of Gas Bubble Dissolution in Groundwater and Its Implications for the Dissolved Gas Composition. Environ. Sci. Technol. 2003, 37 (7), 1337-1343. https://doi.org/10.1021/es025712z.

(31) McLeod, H. C.; Roy, J. W.; Smith, J. E. Patterns of Entrapped Air Dissolution in a TwoDimensional Pilot-Scale Synthetic Aquifer. Groundwater 2015, 53 (2), 271-281. https://doi.org/10.1111/gwat.12203.

(32) Englert, A.; Hubbard, S. S.; Williams, K. H.; Li, L.; Steefel, C. I. Feedbacks Between Hydrological Heterogeneity and Bioremediation Induced Biogeochemical Transformations. Environ. Sci. Technol. 2009, 43 (14), 5197-5204. https://doi.org/10.1021/es803367n.

(33) Li, L.; Steefel, C. I.; Williams, K. H.; Wilkins, M. J.; Hubbard, S. S. Mineral Transformation and Biomass Accumulation Associated With Uranium Bioremediation at Rifle, Colorado. Environ. Sci. Technol. 2009, 43 (14), 5429-5435. https://doi.org/10.1021/es900016v.

(34) Surasani, V. K.; Li, L.; Ajo-Franklin, J. B.; Hubbard, C.; Hubbard, S. S.; Wu, Y. Bioclogging and Permeability Alteration by L. Mesenteroides in a Sandstone Reservoir: A Reactive Transport Modeling Study. Energy Fuels 2013, 27 (11), 6538-6551. https://doi.org/10.1021/ef401446f.

(35) Eggerichs, T.; Opel, O.; Otte, T.; Ruck, W. Interdependencies between Biotic and Abiotic Ferrous Iron Oxidation and Influence of PH, Oxygen and Ferric Iron Deposits. Geomicrobiol. J. 2014, 31 (6), 461-472. https://doi.org/10.1080/01490451.2013.870620.

(36) Drescher, K.; Shen, Y.; Bassler, B. L.; Stone, H. A. Biofilm Streamers Cause Catastrophic Disruption of Flow with Consequences for Environmental and Medical Systems. Proc. Natl. Acad. Sci. U. S. A. 2013, 110 (11), 4345-4350. https://doi.org/10.1073/pnas.1300321110.

(37) Coyte, K. Z.; Tabuteau, H.; Gaffney, E. A.; Foster, K. R.; Durham, W. M. Microbial Competition in Porous Environments Can Select against Rapid Biofilm Growth. Proc. Natl. Acad. Sci. 2017, 114 (2), E161. https://doi.org/10.1073/pnas.1525228113.

(38) Le Borgne, T.; Bour, O.; Paillet, F. L.; Caudal, J.-P. Assessment of Preferential Flow Path Connectivity and Hydraulic Properties at Single-Borehole and Cross-Borehole Scales in a Fractured Aquifer. Meas. Parameterization Rainfall Microstruct. 2006, 328 (1), 347-359. https://doi.org/10.1016/j.jhydrol.2005.12.029. 
(39) Paillet, F. L. Borehole Flowmeter Applications in Irregular and Large-Diameter Boreholes. Non-Pet. Appl. Boreh. Geophys. 2004, 55 (1), 39-59. https://doi.org/10.1016/j.jappgeo.2003.06.004.

(40) Le Borgne, T.; Paillet, F.; Bour, O.; Caudal, J. Cross-Borehole Flowmeter Tests for Transient Heads in Heterogeneous Aquifers. Groundwater 2006, 44 (3), 444-452. https://doi.org/10.1111/j.1745-6584.2005.00150.x.

(41) Pédrot, M.; Dia, A.; Davranche, M.; Gruau, G. Upper Soil Horizons Control the Rare Earth Element Patterns in Shallow Groundwater. Geoderma 2015, 239-240, 84-96. https://doi.org/10.1016/j.geoderma.2014.09.023.

(42) Parkhurst, D. L.; Appelo, C. A. J. Description of Input and Examples for PHREEQC Version 3-A Computer Program for Speciation, Batch-Reaction, One-Dimensional Transport, and Inverse Geochemical Calculations; U.S. Geological Survey Techniques and Methods; book 6, chap. A43, 497 p; 2013; p 497.

(43) Cravotta, C. A. User-Friendly Geochemical Modeling to Evaluate Active and Passive Treatment for Coal Mine Discharges: Proceedings 39th Annual Meeting West Virginia Surface Mine Drainage Task Force : Morgantown; W.Va., West Virginia University, 2018.

(44) Kappler, A.; Emerson, D.; Gralnick, J. A.; Roden, E. E.; Muehe, E. M. Geomicrobiology of Iron. In Ehrlich's geomicrobiology; CRC press: 6000 Broken Sound Parkway NW, Suite 300, 2016; pp 343-399.

(45) Okazaki, M.; Sugita, T.; Shimizu, M.; Ohode, Y.; Iwamoto, K.; de Vrind-de Jong, E. W.; de Vrind, J. P.; Corstjens, P. L. Partial Purification and Characterization of ManganeseOxidizing Factors of Pseudomonas Fluorescens GB-1. Appl. Environ. Microbiol. 1997, 63 (12), 4793-4799.

(46) Hosseinkhani, B.; Emtiazi, G. Synthesis and Characterization of a Novel Extracellular Biogenic Manganese Oxide (Bixbyite-like $\mathrm{Mn}_{2} \mathrm{O}_{3}$ ) Nanoparticle by Isolated Acinetobacter sp. Curr. Microbiol. 2011, 63 (3), 300. https://doi.org/10.1007/s00284-011-9971-8.

(47) Akob, D. M.; Bohu, T.; Beyer, A.; Schäffner, F.; Händel, M.; Johnson, C. A.; Merten, D.; Büchel, G.; Totsche, K. U.; Küsel, K. Identification of Mn(II)-Oxidizing Bacteria from a Low-PH Contaminated Former Uranium Mine. Appl. Environ. Microbiol. 2014, 80 (16), 5086-5097. https://doi.org/10.1128/AEM.01296-14.

(48) Yang, W.; Zhang, Z.; Zhang, Z.; Chen, H.; Liu, J.; Ali, M.; Liu, F.; Li, L. Population Structure of Manganese-Oxidizing Bacteria in Stratified Soils and Properties of Manganese Oxide Aggregates under Manganese-Complex Medium Enrichment. PLOS ONE 2013, 8 (9), e73778. https://doi.org/10.1371/journal.pone.0073778.

(49) Francis, C. A.; Co, E.-M.; Tebo, B. M. Enzymatic Manganese(II) Oxidation by a Marine $\alpha$ Proteobacterium. Appl. Environ. Microbiol. 2001, 67 (9), 4024-4029. https://doi.org/10.1128/AEM.67.9.4024-4029.2001.

(50) Carmichael, M. J.; Carmichael, S. K.; Santelli, C. M.; Strom, A.; Bräuer, S. L. Mn(II)Oxidizing Bacteria Are Abundant and Environmentally Relevant Members of Ferromanganese Deposits in Caves of the Upper Tennessee River Basin. Geomicrobiol. J. 2013, 30 (9), 779-800. https://doi.org/10.1080/01490451.2013.769651.

(51) Poole, R. K. Microbiology of Metal Ions; Advances in Microbial Physiology; Elsevier Science, 2017.

(52) Marcus Daniel N.; Pinto Ameet; Anantharaman Karthik; Ruberg Steven A.; Kramer Eva L.; Raskin Lutgarde; Dick Gregory J. Diverse Manganese(II)-oxidizing Bacteria Are Prevalent 
633

634

635

636

637

638

639

640

641

642

643

644

645

646

647

648

649

650

651

652

653

654

655

656

657

658

659

660

661

662

663

664

in Drinking Water Systems. Environ. Microbiol. Rep. 2017, 9 (2), 120-128. https://doi.org/10.1111/1758-2229.12508.

(53) Takeuchi, M.; Hamana, K.; Hiraishi, A. Proposal of the Genus Sphingomonas Sensu Stricto and Three New Genera, Sphingobium, Novosphingobium and Sphingopyxis, on the Basis of Phylogenetic and Chemotaxonomic Analyses. Int. J. Syst. Evol. Microbiol. 2001, 51 (4), $1405-1417$.

(54) Tauler, M.; Vila, J.; Nieto, J. M.; Grifoll, M. Key High Molecular Weight PAH-Degrading Bacteria in a Soil Consortium Enriched Using a Sand-in-Liquid Microcosm System. Appl. Microbiol. Biotechnol. 2016, 100 (7), 3321-3336. https://doi.org/10.1007/s00253-0157195-8.

(55) Kertesz*, M. A.; Kawasaki, A. Hydrocarbon-Degrading Sphingomonads: Sphingomonas, Sphingobium, Novosphingobium, and Sphingopyxis. In Handbook of Hydrocarbon and Lipid Microbiology; Timmis, K. N., Ed.; Springer Berlin Heidelberg: Berlin, Heidelberg, 2010; pp 1693-1705. https://doi.org/10.1007/978-3-540-77587-4_119.

(56) Stumm, W.; Lee, G. F. Oxygenation of Ferrous Iron. Ind. Eng. Chem. 1961, 53 (2), $143-$ 146. https://doi.org/10.1021/ie50614a030.

(57) Martirani-Von Abercron, S.-M.; Pacheco, D.; Benito-Santano, P.; Marín, P.; Marqués, S. Polycyclic Aromatic Hydrocarbon-Induced Changes in Bacterial Community Structure under Anoxic Nitrate Reducing Conditions. Front. Microbiol. 2016, 7, 1775. https://doi.org/10.3389/fmicb.2016.01775.

(58) Eckert, P.; Appelo, C. A. J. Hydrogeochemical Modeling of Enhanced Benzene, Toluene, Ethylbenzene, Xylene (BTEX) Remediation with Nitrate. Water Resour. Res. 2002, 38 (8), 5-1-5-11. https://doi.org/10.1029/2001WR000692.

(59) Emerson, D.; Scott, J. J.; Benes, J.; Bowden, W. B. Microbial Iron Oxidation in the Arctic Tundra and Its Implications for Biogeochemical Cycling. Appl. Environ. Microbiol. 2015, 81 (23), 8066-8075. https://doi.org/10.1128/AEM.02832-15.

(60) Rose, A. L.; Waite, T. D. Kinetics of Iron Complexation by Dissolved Natural Organic Matter in Coastal Waters. Mar. Chem. 2003, 84 (1), 85-103. https://doi.org/10.1016/S03044203(03)00113-0.

(61) Chen, C.; Thompson, A. Ferrous Iron Oxidation under Varying $\mathrm{pO}_{2}$ levels: The Effect of $\mathrm{Fe}^{\mathrm{III}} / \mathrm{Al}^{\mathrm{III}}$ oxide minerals and organic matter. Env. Sci. Tech. 2018, 52, 597-606. https://doi.org/10.1021/acs.est.7b05102. 